\title{
Büyük Veri ve Derlem Anlambilim Açısından Așk Kavramı: Anlam, Gönderim ve Metafor
}

\section{The Concept of Love From the Perspectives of Big Data and Corpus Semantics: Meaning, Reference, and Metaphor}

\author{
Engin Arık ${ }^{1}$, Beril T. Arık ${ }^{2}$ ()
}

'Doç. Dr., Purdue Üniversitesi, İngilizce Bölümü, HEAV 36D, West Lafayette, IN, USA ${ }^{2}$ Misafir Dr. Öğr. Üyesi, Purdue Üniversitesi, İngilizce Bölümü, HEAV 36D, West Lafayette, IN, USA

ORCID: E.A. 0000-0002-0981-257X; B.T.A. 0000-0002-9894-547X

\section{Sorumlu yazar/Corresponding author: Engin Arık, \\ Purdue Üniversitesi, İngilizce Bölümü, HEAV 36D, West Lafayette, IN, USA \\ E-posta/E-mail: enginarik@enginarik.com}

Başvuru/Submitted: 30.01 .2019 Revizyon Talebi/Revision Requested: 28.02.2019

Son Revizyon/Last Revision Received: 19.04.2019

Kabul/Accepted: 03.05.2019

Online Yayın/Published Online: 31.05 .2019

Atıf/Citation: Arik, E., Arik, B. T. (2019). Büyük veri ve derlem anlambilim açısından aşk kavramı: Anlam, gönderim ve metafor. Psikoloji Çalışmaları - Studies in Psychology, 39(1): 151-178.

https://doi.org/10.26650/SP2019-0011
ÖZ

Farklı disiplinlerde aşk üzerine çalışmalar yapılmakla birlikte aşk soyut bir kavram olduğu için tanımlanması oldukça güçtür. Disiplinlerarası aşk çalışmalarına katkıda bulunmayı amaçlayan bu çalışma, aşkın Türkçe'de ne anlama geldiğini ve dilde kullanımını bilgisayarlı dilbilim ve derlem yöntemleriyle analiz ederek aşk kavramının ilkörneğini ortaya koymaktadır. Çalışma kuramsal olarak İlkörnek Kuramı ile Derlem Anlambilim kuramlarını kullanıp Derlem ve Büyük Veri analiz yöntemlerinden yararlanmaktadır. İlkörnek kuramına göre ilkörnek bir sınıfın belli başlı özelliklerini taşımaktadır. Şeyler beyinde kategorize edilirken ilkörneklere benzerliklerine göre sınıflandırılırlar. Kategoriler arasında geçişler çok kesin değildir. Bazı şeyler ilkörneğe daha çok benzeyip kavramı daha çok temsil ederken, bazıları daha az benzeyip kavramı daha az temsil etmektedirler. Derlem anlambilim kuramına göre ise, bir sözcüğün anlamı, sözcüğün çekimli hallerini de kapsayan sözcüğün özüne, bu sözcükle beraber kullanılan diğer sözcüklere, sözcüğün içinde bulunduğu dilbilgisel yapılara, konuşucuların bilgi, tavır ve tutumları ile dış dünya bilgisine ve metin / konuşma türüne dayanmaktadır. Çalışmanın verisi Türkçe Ulusal Derlemi’nden aşk sözcüğünün geçtiği 2,500 satır, 10,671 farklı sözcük ve toplam 27,855 sözcükten ve Twitter'dan 85,980 kısa mesaj (tweet) 130,016 farklı sözcük ve toplam 1,280,736 sözcükten oluşmaktadır. Analiz sonuçlarına göre aşk, NITELIK, NICELIK, ZAMAN, YER, GERÇEKLIK, ZIHIN, BEDEN, DIL, INANÇ, ŞEY, KIŞI, BITKI ve TAŞIT ilkörnekleriyle bağlantılı bir kavram olup bu ilkörneklerle ilgili kavramlarla birlikte sıklıkla kullanılmaktadır. Aşk hem pozitif hem negatif duygu ifadeleriyle birlikte kullanılmaktadır. Ayrıca, aşk yakın ilişki ve bağlanma ile ilgili sözcüklerle ifade edildiği gibi gerçek olmayan bir bağlanmayı, nesne veya gruba bağlanmayı ve bağlanmasız ilişkileri de içermektedir. Dolayısıyla, aşkın anlamı bağlama göre değişken olup dilin resmi ve gündelik kullanımlarına göre de çeşitlilik göstermektedir. Bu nedenlerle, hem gözlem / görüşme yapılan çalışmalarda hem de deneysel çalışmalarda bu kavramların kullanımına dikkat etmek, geliştirilen ölçüm araçlarındaki tanımlar ve katılımcıların kullandığı kavramlar arasındaki farklılıkların araştırma sonuçlarını etkileyebileceği göz ardı edilmemelidir. Anahtar Kelimeler: Aşk, kavram, anlam, duygu, büyük veri, derlem 


\section{ABSTRACT}

While love has been investigated by scholars in various disciplines, defining this abstract and evasive concept is a daunting task. In order to contribute to the multidisciplinary studies on love, this study investigates the meaning of love and its uses in everyday life in Turkish to provide its prototypes, using computational linguistics and corpus-based methods. The study follows the Prototype Theory and Corpus Semantics and applies corpus and Big Data methods. The data consisted of formal and colloquial dictionaries published by the Turkish Language Association; 2,500 lines, 10,671 types, and 27,855 tokens from the Turkish National Corpus; and, 85,980 short messages (tweets), 130,016 types, and 1,280,736 tokens from Twitter. The results showed that the love concepts were related to prototypes such as QUALITY, QUANTITY, TIME, PLACE, REALITY, MIND, BODY, LANGUAGE, BELIEF, THING, PERSON, PLANT, and VEHICLE. The results also showed that love in Turkish was not only related to positive emotions such as compassion and fun but also negative emotions such as pain and hate. Therefore, love was associated with both positive and negative emotion concepts. There were differences between the definitions of love, including idiomatic expressions in the formal dictionaries and the language used in daily life, because love was used not only in relation to intimate relationships or attachment but also in the context of pain, hate, illness, etc. Love was related to close relationships including both real and imaginary attachment. The meaning of love also differed depending on the context and with regard to (in)formal use of the language.

Keywords: Love, concept, meaning, emotion, big data, corpus

\section{EXTENDED ABSTRACT}

This study investigates the meaning of love in Turkish, using Big Data (National Institute of Standards and Technology [NIST], 2015) obtained from a corpus and social media. Love is defined as one's commitment and/or attachment to somebody else, often involving a sexual relationship. However, debate exists over whether or not love is an emotion (Felmlee \& Sprecher, 2006). Previous research has shown that love can be categorized in many ways, from romantic love to love for family members (Lee,1988; Murstein, 1977; 1988; Regan, 2011, 2016; Regan, Kocan, \& Whitlock, 1998; Shaver, Schwartz, Kirson, \& O'Connor, 1987; Sternberg, 2006). Nevertheless, a layperson's definition of love can differ from the definitions used in literature/art and science. To contribute to this field of inquiry, following two theoretical approaches, the prototype theory (Goldstone, Kersten, \& Carvalho, 2017; Rosch, 1978, 1999; Rosch \& Mervis, 1975) and corpus semantics (Sinclair, 1991, 2004; Stubbs, 2001, 2009), we provided a definition of love in Turkish, on the basis of corpus and social media data.

The prototype theory suggests that people categorize things based on those things' resemblance to the most typical example in a category. Corpus semantics argues that a word's meaning is not restricted to the traditional definitions that appear in dictionaries or to its denotations and connotations as argued in traditional linguistics. In addition to these, meaning is based on the use of the word and the (linguistic) context in which the word appears, such that the frequency of the targeted word, its linguistic forms, the words that co-occur with the targeted word, phrasal structures, and genre all contribute to the targeted word's meaning. Following these theories, we aim to find the most central definition of love in Turkish on the basis of its use in (in)formal contexts. 


\section{Method}

The data consisted of formal and colloquial dictionaries published by the Turkish Language Association; 2,500 lines, 10,671 types, and 27,855 tokens from the Turkish National Corpus; and, 85,980 short messages (tweets), consisted of 130,016 types, and 1,280,736 tokens from Twitter. The tweets were obtained automatically using Rich Site Summary (RSS) and Application Program Interface (API) between December 2017 and December 2018. Each line or tweet contained the word aşk (Eng. love) at least once. The data were analyzed by the type / token frequencies, logged frequencies, Mutual Information (MI), entropy and relative entropy, lexical gravity $(\mathrm{G})$, probabilistic uncertainty $(\Delta \mathrm{p})$, and Log-Likelihood (LL or $\left.\mathrm{G}^{2}\right)$. For frequencies, MI, and LL, the software programs AntConc and Lancsbox were used.

\section{Results}

The results showed differences between the definitions of love, including idiomatic expressions in the formal dictionaries and the language used in daily life, because love was used not only in relation to intimate relationships or attachment but also in the context of pain, hate, illness, etc. The results also showed that love in Turkish was not only related to positive emotions such as compassion and fun but also negative emotions such as pain and hate. Therefore, love was associated with both positive and negative emotion concepts.

A closer examination of the data indicated that the concepts were related to prototypes such as QUALITY, QUANTITY, TIME, PLACE, REALITY, MIND, BODY, LANGUAGE, BELIEF, THING, PERSON, PLANT, and VEHICLE. Love was related to close relationships including both real and imaginary attachment. The objects of attachment included not only persons but also collective things such as a soccer club. The duration of love could be very temporary or prolonged, even eternal. The meaning of love also differed depending on the context and with regard to (in)formal use of the language. For example, the Turkish National Corpus contained frequent uses of love stories, love poems, and love in families, which were significantly greater in number than the uses that appeared on Twitter. By contrast, there were frequent uses of love pains and extramarital love, which were significantly greater in number than the uses that appeared in the Turkish National Corpus.

\section{Discussion}

These findings contribute to the study of abstract concepts such as love and their meanings in daily life. This study highlights the importance of using new methods and perspectives such as Big Data and corpus semantics to examine the meaning of love. Because differences were found in the formal definitions of love and its meanings in formal 
use, as in the corpus and in daily use in the social media, the study calls for additional studies in this domain, especially studies of lexicography and theoretical and experimental studies of intimate relationships. Our future studies will investigate the meaning of love by considering love to be a lemma and by also focusing on its derivations and inflected forms. Researchers should take many meanings of love into account depending on the language usage when they develop tools and inventories to measure love and intimate relations. 
Aşkın anlamı, bir duygu olup olmadığı, anlamının kişiden kişiye farklılıklar gösterip göstermediği bilimsel olarak farklı disiplinlerce incelenmektedir. Bu disiplinler arasında psikoloji, dilbilim, sinirbilim, sosyoloji, antropoloji, tarih ve felsefe gibi disiplinler yer almaktadır. Aşkın edebiyat, sinema, tiyatro ve müzik gibi sanat alanlarında temel konu olduğu da düşünüldüğünde bilimsel olarak aşkın anlamı konusu oldukça önem arz etmektedir. Bir bilişsel psikoloji kuramı olan İlkörnek Kuramı'nın kullanılması (Rosch, 1978, 1999; Rosch ve Mervis, 1975), bilgisayarlı dilbilim ve derlem dilbilim yöntemleriyle analiz yapılması (Sinclair, 1991, 2004) ve sonuçların anlambilim ve metafor çalışmalarına (Stubbs, 2001, 2009; Kövecses, 1991, 2008) katkısından dolayı bu çalışma disiplinlerarası bir çalışmadır. Çalışmada, aşkın Türkçe'de ne anlama geldiğine ve resmi / kuralcı ve günlük dilde kullanımına odaklanılarak aşk kavramının ilkörneğini (İng. prototype) çıkartmak hedeflenmektedir.

\section{Kuramsal Çerçeve}

Aşk olgusu üzerine sınıflandırmacı (Murstein, 1977, 1988), üçgensel aşk (Regan, 2011, 2016; Regan, Kocan ve Whitlock, 1998; Sternberg, 2006), aşk tipolojisi (Lee,1988) gibi kuramsal yaklaşımların yanı sıra ilkörnek kuramı (İng. prototype theory) gibi yaklaşımlar da mevcuttur (Shaver, Schwartz, Kirson ve O’Connor, 1987). Bu çalışmada aşkın anlamını ortaya çıkartmak için ilkörnek kuramı ile derlem anlambilim (İng. corpus semantics) kuramları kullanılmaktadır (Stubbs, 2001, 2009). Kavramların sınıflandırılması için önerilen bilişsel bilimler teorilerinden birisi olan ilkörnek kuramına göre (Rosch, 1978, 1999; Rosch ve Mervis, 1975; daha güncel çalışmalar için Goldstone, Kersten ve Carvalho, 2017) ilkörnek bir sınıfın belli başlı özelliklerini taşımaktadır. Şeyler beyinde kategorize edilirken ilkörneklere benzerliklerine göre sınıflandırılırlar. Kategoriler arasında geçişler çok kesin değildir. Bazı şeyler ilkörneğe daha çok benzeyip kavramı daha çok temsil ederken, bazıları daha az benzeyip kavramı daha az temsil etmektedirler. Klasik bir örnek vermek gerekirse, kuş kategorisinde serçe, karga, güvercin gibi hayvanlar daha belirginken tavuk, devekuşu gibi hayvanlar daha az belirgin olmaktadır.

İlkörnek kuramına göre aşk şu şekilde açıklanmaktadır (Rosch, 1978; Shaver, Schwartz, Kirson ve O'Connor, 1987 vb.). Aşk, DUYGUların bir alt kategorisidir. Ancak, aşkın bir üst kategorisi alt kavramları öfke, korku ve mutsuzluk olan, NEGATİF DUYGUlar değildir. Aşkın bir üst kategorisi POZITİF DUYGUlar olup delicesine aşk, anne sevgisi / aşk1, romantik aşk ve arkadaşılık kavramları aşkın alt kategorilerini oluşturmaktadır. Bu kurama göre, mutluluk ise aşk gibi pozitif bir duygudur. 
Ancak, aşkın hem temel bir duygu olduğunu hem de olmadığını savunan pek çok görüş mevcuttur (Felmlee ve Sprecher, 2006). Aşk temel bir duygu değildir çünkü, 1) öfke, tiksinme, üzüntü, korku, mutluluk ve şaşkınlık gibi temel duygular belli ve farklı yüz ifadeleriyle gösterilebilirken (Ekman, 1992), aşk belli bir yüz ifadesiyle gösterilememektedir. 2) Aşk bir duygudan ziyade açlık, susuzluk ve uyku gibi temel dürtülerden birisidir (Rempel ve Burris, 2005). Fakat, aşk temel bir duygu olarak da görülebilir çünkü 1) aşk tarihsel olarak ve günümüzde bütün kültürlerde ve farklı yaş gruplarında gözlemlenebilmektedir (Jankowiak ve Fischer, 1992). 2) Uzun süreli olan ilişkisel aşk temel duyguların yanı sıra sıkıntı ve kaygı gibi duyguları da içeren daha kapsamlı bir duygudur. Aşkı sadece duygu olarak kategorize etmek eksik kalmaktadır çünkü aşk aynı zamanda bağlanmay1, birbirine özen göstermeyi ve cinsel ilişkiyi de içerir (Shaver, Morgan ve Wu, 1996). $\mathrm{Bu}$ nedenlerle, bu çalışmada aşkın hem nasıl bir duygu olduğu hem de duygu dışında hangi ilkörneklerle ilişkili olduğu yeni verilerle ortaya konulacaktır.

Bu çalışmada ilkörnek kuramına ek olarak, Büyük Veri analizlerinden yararlanılmaktadır. Büyük Veride veri, büyük hacimli, çeşitli (düzenli ve düzensiz), kendi içinde değişken ve hızla elde edilebilen ve değişen geniş/büyük veri kümeleridir. Bu veri kümeleri etkin depolamaya, işlemeye ve analize açık olmalıdır (National Institute of Standards and Technology [NIST], 2015, s. 5). Son yıllarda giderek artan bir şekilde bilgisayar bilimleri, hesaplamalı dilbilim, işletme ve derlem dilbilimi alanlarında Büyük Veriden yararlanılmaktadır. Bu tür verilerle sosyal bilimlerde ne tür analizlerin yapılabileceğine dair rehber kitaplar da yayınlanmıştır (örn., Foster, Ghani, Jarmin, Kreuter ve Lane, 2017). Psikoloji alanında da Büyük Veriye ilgi oluşmaya başlamıştır (örn., Cheung ve Jak, 2016). Bu nedenlerle, bu çalışmada sosyal medyadan elde edilen Büyük Veri kullanılmaktadır.

Bu çalışmada Büyük Veri analizlerinin yanı sıra Derlem Anlambilim kuramından da yararlanılmaktadır. Derlem anlambilim kuramının en belirgin özelliklerinden birisi de anlamı ortaya çıkartmak için herkese açık, gözlemlenebilir ve mümkün olduğunca çok doğal veriden yararlanılmasıdır. Bilgisayar bilimleri ve dilbilim alanlarının etkileşiminin artmasıyla dilbilim alanında ortaya çıkan derlem anlambilim kuramına göre anlam sadece sözcüklerin sözlüksel anlamlarından ibaret değildir (Sinclair, 1991, 2004; Stubbs, 2001, 2009; ilgili çalışmalar için örneğin bknz. Glynn ve Robinson, 2014). Anlam; bağlamdan, kullanımdan ve kültürel özelliklerden bağımsız değildir. Klasik anlambilim çalışmalarında, anlam için ayrıca sözcüğün objektif düz anlamı (İng. denotation), subjektif yan anlamı (İng. 
connotation) ve çok anlamlılığı (İng. polysemy) da göz önüne alınmaktadır. Derlem anlambilim kuramı da bunlardan yararlanır ancak sadece bunlarla yetinmez.

Derlem anlambilim kuramına göre bir sözcüğün anlamı, sözcüğün çekimli hallerini de kapsayan sözcüğün özüne (İng. lemma), bu sözcükle beraber kullanılan diğer sözcüklere (eşdizimli sözcükler, İng. collocations), sözcüğün içinde bulunduğu dilbilgisel yapılara (İng. colligations), konuşucuların bilgi, tavır ve tutumları ile dış dünya bilgisine (İng. discourse prosody) ve metin / konuşma türüne (İng. genre) dayanmaktadır. Çok basitleştirerek bir örnek vermek gerekirse, aşağıdaki cümlelere bakıldığında kedi sözcüğünün özünün kedi olduğu, fare ve köpek gibi hayvanlarla ilişkisi, evde insanlarla beraber veya ev dışında yaşayabileceği, sütle beslenebileceği, insanların kediye benzetilebileceği, kedinin sayılabilir olduğu gibi çıkarımlar rahatlıkla yapılabilir. Derlem anlambilim kuramına göre, bu cümleler ve metin / konuşma parçaları sayısal olarak arttıkça kedinin anlamı daha da belirginleşecektir.

Eve bir kedi almıştı.

Kedi fareyle oynad1.

Kedi köpek gibi kavga ettiler.

Kedi canını senin!

Sonra süt dökmüş kedi gibi girdi içeri.

\section{Aşk, dilde anlam ve metafor}

Aşk ve dil çalışmaları aşkın anlamına ve metaforlarına odaklanmıştır. Türkçe'de metaforlar (eğretileme) üzerine çalışmalar mevcutken bilindiği kadarıyla aşkın sözcüksel anlamı üzerine dil çalışmaları yapılmamıştır ve bu çalışma bu anlamda bir ilk niteliği taşımaktadır. 1980'lerden bu tarafa yapılan dil çalışmalarından bir kısmı aşk (İng. love) ve aşık olma (İng. in love) arasındaki farklara odaklanmıştır. İngilizce üzerine yapılan üniversite öğrencilerinin katılımcı olduğu deneysel bir çalışma (Meyers ve Berscheid, 1997), aşk ve aşık olma kavramlarının kapsamının birbirlerinden farklı olduğunu; bir üst kategori olarak aşk kategorisinin aşık olma kategorisini kapsayabileceğini; aşk kategorisinin değil, aşık olma kategorisinin cinsel arzu ve çekicilik kategorisine dahil olabileceğini bulmuştur.

1980'lerden bu tarafa yapılan dilbilim çalışmalarından diğer bir kısmı ise Bilişsel Dilbilim yaklaşımında kullanılan kuramlardan birisi olan Kavramsal Metafor Kuramı'nı kullanmıştır. Kavramsal Metafor Kuramı'na göre bir deneyim alanı başka daha somut 
bir deneyim alanı ile anlaşılabilmektedir (çıkış noktası için bkz. Lakoff ve Johnson, 1980). Kövecses bu kuramı duygu sözcükleri ve kavramlarına uyarlayarak aşkla ilgili kullanılan 'aşk deliliktir' gibi (bilişsel) metaforlara, 'aşık olunca başka bir şey düşünememe' gibi metonimlere (ad aktarması), bunlarla ilgili kavramlara ve bilişsel modellere odaklanmıştır (Kövecses, 1991). Kövecses'e göre aşkın kaynak metaforları BİRLİK, BESIN, DEĞERLİ BİR ŞEY, KAPTA BİR SIVI, ATEŞ, DOĞA GÜCÜ / OLAYI, FİZİKSEL GÜÇ, SİHİR, DELİLİK ve KENDİNDEN GEÇME'dir. AŞK BİR BESINNDİR olarak formüle edilen BESIN metaforu, örneğin, aşka açım, aşksız yaşayamam ifadelerinde kullanılmaktadır. Sonraki çalışmalar bu metaforlara yenilerini eklemiştir (Kövecses, 2008). Bunlar arasında BAĞ, TUTSAK HAYVAN, HASTALIK, YOLCULUK, SOSYAL ÜSTÜNLÜK, MADDİ DEĞİŞ TOKUŞ, RAKİ, YAKINLIK, OYUN, SAVAŞ, AŞKIN NESNESİ TAPINILAN BİR ŞEYDİR, AŞKIN NESNESİ DEĞERLİ BİR ŞEYDİ, AŞKIN NESNESİ (İŞTAH AÇICI) BİR YİYECEKTİR ve AŞKIN NESNESİ SAHIP OLUNAN BİR ŞEYDİR metaforları da yer almaktadır.

Aşkın metonimleri ise vücut ısısının artması, kalp atışının artması, kızarma, baş dönmesi, fiziksel güçsüzlük / halsizlik, terli eller / avuç içleri, nefes alamama / nefessiz kalma, düzgün düşünememe / iyi algılayamama, düşünememe, biriyle meşgul olma, fiziksel yakınlık, seks ve sevgi dolu görsel davranışlar / bakışlar ve mesut bakışlardır (Kövecses, 1991). Fiziksel güçsüzlük metonimi için o benim dizlerimin bă̆ını çözüyor, kızarma metonimi için onu görünce yüzü kızardı örneği, nefessiz kalma metonimi için sen benim nefesimi kesiyorsun örnekleri verilebilir. Aşk kavramları ve metaforlarla ilgili başka çalışmalarda ise bu metaforların tarihsel olarak kullanımı ve değişimi (Tissari, 2001), kişiler tarafından yorumlanışı (Lee ve Schwarz, 2014), İngiliz Ulusal Derlemi (BNC) ve Güncel Amerikan İngilizcesi Derlemi (COCA) kullanarak çeşitli metinlerde kullanımı (Aksan ve Aksan, 2010), farklı dil ve kültürlerde kullanımı (örn., Aksan ve Kantar, 2008a, 2008b; Schröder, 2009) gibi konular araştırılmıştır.

Başka dillerde olduğu gibi Türkçe'de de aşk ve aşık ile ilgili aşağıdaki metaforlar bulunmuştur (Aksan ve Kantar, 2008a, ss. 286-289). Bunlar arasında:

DOĞA GÜCÜ: Ben sırılsıklam aşı̆̆ım.

FİZIKSEL GÜÇ: Aşk yaşadığın bir elektrik.

DELİLIK: Aşkından deli divane ol.

KENDINNDEN GEÇME: $O$ aşkından sarhoş oldu. 
SİHİR: $O$ aşk tılsımına tutuldu.

KAPTA BİR SIVI: Aşkla doldu taştı.

ATEŞ: Aşkından yandı tutuştu.

SAVAŞ: Kalbini fethet/kazan.

RAKİP: $O$ aşka korkusuzca direndi.

SOSYAL ÜSTÜNLÜK: Aşk ferman dinlemez.

BİRLIK: Birbirimiz için yaratılmışız.

BAĞ: Sevda bağladı beni.

BESİN: Aşka aç.

HASTALIK: Aşk geçici bir hastalık.

GIZLENMIŞ ŞEY: Aşkı arıyor.

CANLI ŞEY: Aralarında aşk doğdu.

OYUN: Aşk iki kişilik bir oyun.

YOLCULUK: Bu aşk çıkmaz bir sokaktı.

YAPILI ŞEY: Bu ilişki için bir şeyler yapmalısın.

MADDİ DEĞİŞ TOKUŞ: Bütün fedakarlı̆̆ı ben yaptım.

AŞKIN NESNESİ İŞTAH AÇICI BİR YIYYECEK: Tatlım, seni seviyorum.

AŞKIN NESNESİ KÜÇÜK BİR ÇOCUK: Bebek, ne yapıyoruz?

AŞKIN NESNESİ DEĞERLİ BİR ŞEY: Sultanım başımın tacısın.

AŞKIN NESNESİ SAHIP OLUNMUŞ BİR ŞEY: Sen benimsin.

AŞKIN NESNESİ TAPINILAN BİR ŞEY: Sana hayranım.

AŞK ÇİLE ÇEKMEKTİR: Aşık sevdiğinin derdini ve çilesini çeker.

AŞK ANLATILMAZ BİR ŞEYDİR / AŞK ANLATILAMAZ: Aşk anlatılamaz sadece yaşanır.

AŞK ÖLÜMCÜL BİR GÜÇTÜR / AŞK ÖLÜMCÜLDÜR: Aşk insanı ölüme götürür. AŞK FEDAKARLIKTIR: Kendimi sana feda ettim.

AŞK ESARETTİR: Aşkından esaretim.

AŞKIN NESNESİ BİR KATİLDİR / AŞK ÖLDÜRÜCÜDÜR: Sen de mi öğrendin cefa klmayl? 
AŞKIN NESNESİ BİR IYYILEŞTİRICIDİR / AŞK IYYILEŞTIRIIR: Sana dermana geldim.

Türkçe'de uzuvlarla (İng. body-parts) ilgili deyimlerden türeyerek kavramsallaşmış duygular üzerine yapılan bir çalışmada, yukarıdaki metaforlara yeni metaforlar eklenmiştir (Baş, 2015, ss. 180-191):

KAPTA BİR SIVI: Kalbi boş olmak.

ATEŞ: Yüreğinden sıcak sıcak alev çıkmak.

BİRLİK: Kalp kalbe karşıdır.

BAĞ: Yürekten bağlanmak.

BESIN: Kalbi aç.

AŞK KALPTEN NAKLEDİLİR: Yüreği akmak.

AŞK BAŞKASININ KALBİNE SAHIP OLMAKTIR: Kalbini çalmak. Kalbini kazanmak.

AŞK SICAKLIKTIR: Sicak yüz göstermek.

AŞK GÖZDE / KALPTE / DAMARDADIR. Gözde olmak. Kalbine girmek. Damarina girmek.

AŞK GÖZE BİR PERDEDİR. Gözünü sevda (aşk) bürümek.

AŞK BİR VECD HALİİR. Başı dumanlı.

AŞK GÖZDE İLAHİ BİR IŞIKTIR / NURDUR. Gözümün nuru.

AŞK ELDEDİR / BAŞTADIR. El üstünde tutmak. Baş tacı etmek.

AŞK GÖZDE BİR SIKINTIDIR. İlk göz ă̆rısı.

AŞKIN NESNESİ HAYATİ BİR ORGANDIR. Ciğer parçası. Gözü gibi sevmek.

Bu çalışmanın amacı psikoloji ve dil çalışmaları yaklaşımları çerçevesinde büyük veri kullanarak Türkçe'de aşkın anlamını ve ilkörneklerinin neler olduğunu bulmaktır. Araştırma soruları ise şu şekildedir: Aşkın sözlüksel anlamı ile dilde kullanımı arasındaki farklar nelerdir? Aşk kavramı sadece (pozitif) duygu ifadelerinde mi kullanılmaktadır? Aşk kavramı resmi / kuralcı dilde ve günlük dilde farklı anlamlara gelmekte midir? Daha önceki çalışmalardan farklı olarak bu araştırmada, 
(1) aşk sözcügünün geçtiği deyim ve atasözleri de taranmaktadır,

(2) resmi ve günlük dilde kullanımlarına erişmek için Türkçe derlemden ve sosyal medya verilerinden yararlanılmaktadır,

(3) aşk sözcüğü yapısal olarak da incelenmektedir ve

(4) bu sözcüğün hangi bağlamlarda ve hangi sözcüklerle beraber kullanıldığı, hangi tamlamalarda ve hangi görevlerde (örn., isim, sıfat) kullanıldığg da incelenmektedir.

\section{YÖNTEM}

\section{Veri}

Bu çalışmada veriler üç çeşit kaynaktan elde edildi. İlk kaynak Türk Dil Kurumunun (TDK) güncel, büyük ve ağız / lehçe çevrimiçi sözlükleri ile atasözleri ve deyimler çalışmalarıydı (Türk Dil Kurumu Sözlükler, t.y.). İkinci ve üçüncü kaynak olarak Büyük Verilerden yararlanıldı.

İkinci kaynak ise toplam 50 milyon sözcükten oluşan ve temsil yeterliliği oldukça iyi bir derlem olan Türkçe Ulusal Derlem olarak seçildi (TUD; Aksan ve ark., 2012). TUD bilimsel kitaplar, gazeteler, hikayeler gibi çeşitli kaynaklardan elde edilen metinlerden oluşmaktadır. Toplam veri kaynağı sayısı 4,438 olup, metinler 9 farklı konu alanından ve 34 farklı metin türünden alınmıştır. Bu çalışmada TUD’dan yararlanılarak Türkçe standart / resmi farklı metin türlerinde aşkın nasıl kullanıldığını ortaya çıkartmak hedeflendi.

İlk iki tür kaynaktan Türkçe'nin standart kullanımına erişildi. Üçüncü kaynak olarak sosyal medyadan yararlanıldı ve böylelikle Türkçe konuşucularının aşkı günlük, resmi olmayan / gündelik dilde kullanımına erişildi. Statista.com, statcounter.com gibi websitelerine göre Türkiye'deki aktif twitter kullanıcı sayısı 9 milyona yakındır ve Türkiye aktif kullanıcı sayısı açısından ABD, Japonya, İngiltere ve Suudi Arabistan'dan sonra dünyada 5. sıradadır. $\mathrm{Bu}$ nedenle Twitterdan veri elde etmek anlamlıdır. Bu çalışmada, Aralık 2017-Aralık 2018 arasında Rich Site Summary (RSS) ve Twitter beslemeleri (API) arac1lığıyla otomatik olarak veri toplandı. İnternet erişimi olan herkesin bilgisayar, akıllı telefon gibi araçlarla kişisel hesap açarak kullanabildiği bir sosyal ağ olan Twitter, 2006 y1lindan beri kullanılmaktadır. Twitterda mesajlar Kasım 2017'den bu tarafa 280 karakterle sınırlandırılmıştır ve bu çalışmadaki sosyal medya verisi 280 karakterle sınırlandırılmış twitlerden oluşmaktadır. Kullanıcılar twitlerini sadece takipleştiği kişilerle veya herkese açık bir şekilde paylaşmaktadırlar. Twitter kişisel görüşleri paylaşmanın yanı sıra anlık 
haberleşmeye izin vermesi nedeniyle bireysel gazetecilik, afet durumlarında haberleşme, siyasi olaylara aktif katılım, sağlık bilgilerini paylaşma gibi durumlarda sıklıkla kullanılmaktadır (Murty, 2018). Siyasi bilimler, iletişim gibi sosyal bilim alanlarında olduğu gibi psikoloji bilimlerinde de Twitter kullanımı ve Twitter'dan elde edilen veriler üzerine araştırmalar yapılmaya başlanmıştır (örn., Eichstaedt ve ark., 2015).

\section{İşlem}

Her üç kaynakta da anahtar sözcük olarak 'aşk' sözcüğü kullanıldı. Elde edilen bütün veriler .xlsx ve .txt formatlarında kaydedildi. Twitter'da anlık paylaşım yapıldığ 1 için ve twitler sonradan kullanıcı dışında bir editör tarafından düzeltilmediği için resmi dile uygun olmayan dil kullanımları ve yazım hataları olabilmektedir. Twitter mesajlarında günlük dil kullanımını hedeflenildiği için (resmi dile göre) dilbilgisi hataları düzeltilmedi, sadece araştırma sorularıyla ilgili olan, aşk yerine ask yazmak gibi, yazım hataları düzeltildi ki hem aşk hem de ask olarak iki ayrı kavram ortaya çıkmasın. Ayrıca, Türkçe yerine tamamen başka dilde yazılmış twitler analizden çıkarıldı, fakat hem Türkçe hem başka bir dilde karmaşık yazılmış twitler analizden çıkartılmadı çünkü bu tür twitler günlük dilin bir parçası olmaktadır. Twitter'da diğer sosyal medya araçlarında olduğu gibi az miktarda da olsa botlar kullanılarak otomatik mesajlar üretilebilmektedir. Bunları ayırt etmek oldukça güç olduğu ve sayısal olarak oldukça az oldukları için (varsa) bu tür mesajlar analizden çıkartılmadı. Twitterdan elde edilen verilerde kopyala-yapıştır veya RT şeklinde tekrarlanan twitler teke indirildi. Ayrıca, etik kurallara uymak amaciyla (British Psychological Society, 2017; Williams, Burnap ve Sloan, 2017), sadece herkese açık twitlere erişip, kayıt tarihi hariç, twitte yer almayan twitter hesap ismi, özel isim, telefon numarası, e-posta adresi, fotoğraf, video gibi kişisel bilgiler analize dahil edilmedi. Twit içerisinde geçse dahi fotoğraf ve video gibi görsel materyaller analizden çıkartıldı. Twit içerisinde geçen kişisel bilgi, köprü ve bağlantıları analize dahil edilmekle birlikte makalede bu bilgilere yer verilmedi. Dosyalar birleştirilip tek bir xlsx ve txt dosyası haline getirildi ve ardından analiz edildi.

\section{Analiz}

$\mathrm{Bu}$ çalışmada elde edilen verilerin analizlerinde derlem-bazlı çalışmalarda sıklıkla kullanılan AntConc (Anthony, 2018) ve Lancsbox (Brezina, McEnery ve Wattam, 2015) yazılımlarından yararlanıldı. Elde edilen verilerle betimleyici olarak sözcük, eşdizim ve çok sözcüklü birimlerin sözcük ve farklı sözcük sıklık (İng. type / token frequency) ve $\log ($ aritmik) sıklık analizleri yapıldı. Çıkarsamalı olarak ise, sözcüklerin bir arada kulla- 
nılıp kullanılmadığını anlamak için, birliktelik bilgisi (İng. Mutual Information, MI), entropi ve göreli entropi $\left(\mathrm{H}_{\mathrm{rel}}\right)$, sözcüksel çekim (İng. lexical gravity, $\left.\mathrm{G}\right)$, olasılık değişisimi $(\Delta \mathrm{p})$ analizleri yapıldı. Veri kaynaklarının birbirleriyle benzerliklerini ve farklılıklarını bulmak için ise, Log-Likelihood (LL veya $\mathrm{G}^{2}$ ) analizleri kullanıldı (genel bilgi için bknz. Gries, 2010, 2015; Oakes, 1998; Stubbs, 1995).

Derlem anlambilime göre, aynı metin içerisinde bulunan sözcükler anlama katkıda bulunmaktadır. $\mathrm{Bu}$ nedenle verilerde hedeflenen sözcük dışında kullanılan sözcüklere de bakmak gerekmektedir. Bunun için ham sözcük sıklıkları hesaplanmalıdır. Ancak, derlem çalışmalarında bilindiği üzere, herhangi bir derlemde / metinde en sık kullanılan sözcükler her zaman bir, ve, bu gibi işlevsel sözcüklerdir. Bu nedenle, hem işlevsel sözcükler hem de içerik sözcükleri sıklıkları göz önüne alınmalıdır. Sözcük sıklıklarının yanı sıra log sıklıklarını da hesaplamak gerekmektedir. Log sıklık ya da ham sıklığın logaritmik değeri psikodilbilim çalışmalarında da gözlenen sıklık etkisini ölçmek için kullanılmaktadır çünkü sözcüğün tanınması (İng. recognition), göreli sıklık değerinin logaritmik değeridir. Log sıklık değeri arttıkça sözcüğün tanınması artmaktadır.

Derlem anlambilime göre, aynı metin içerisinde bulunan sözcükler anlama katkıda bulundukları gibi, hedeflenen sözcüğün etrafındaki (önce ve sonra gelen pozisyondaki) sözcükler de anlama katkıda bulunmaktadır. Bunun için $\mathrm{MI}, \mathrm{H}_{\text {rel }}, \mathrm{G}$ ve $\Delta \mathrm{p}$ değerleri hesaplanmalıdır. MI değeri, gözlemlenen sıklık ile beklenen sıklık arasındaki farkı belirten bir istatistik olup sözcüklerin birlikte olma olasılığını ölçmektedir. MI değeri 3.0'dan büyükse sözcüklerin birlikte olma olasılığı, olmama olasılığından anlamlı biçimde yüksek olarak kabul edilmektedir. $\mathrm{H}_{\text {rel }}$ gözlemlenen verideki dağılımın rastlantısallığını ölçmektedir. $\mathrm{H}_{\text {rel }}$ 0.0'a yaklaştıkça sözcüklerin dağılımının oldukça farklı olduğu, 1.0'a yaklaştıkça sözcüklerin dağılımının denk olduğu belirtmektedir. G ile ise sözcüklerin birlikte bulunma sıklı̆̆1 ile farklı sözcüklerin veride yer alması arasında bağlantı kurup sözcüklerin birbirlerine çekimi, yani bir arada oluşları, ölçülmektedir. G değeri 0.0'a yaklaştıkça sözcükler arası çekim azalmakta, 0.0'dan uzaklaştıkça çekim artmaktadır. Bağlantısal / çağrışımsal öğrenme alanyazınından uyarlanan $\Delta \mathrm{p}$ ile sözcüklerin birlikte olma olasılıkları ile olmama olasılıkları karşılaştırılmaktadır. $\Delta$ p 0.0'a yaklaştıkça sözcükler arası bağlantı azalırken, +1.0'a yaklaştıkça sözcükler arası bağlantı / çekim, -1.0'a yaklaştıkça itim / uzaklaşma artmaktadır.

Derlem anlambilime göre, anlam bağlamdan bağımsız olamayacağı için farklı kaynaklardan elde edilen verilerin karşılaştırılıp birbirleriyle örtüşmeleri de incelenmelidir çünkü 
farklı kaynaklardan (İng. genre) edinilen veriler farklı anlamları oluşturabilmektedirler. Olabilirlik oranı (LL) ile, verideki anahtar sözcükler bulunması ve metinler arası benzerlik ve farklılıkları istatistiksel olarak bulmak amaçlanmaktadır. LL, özellikle iki veri setinin birbiriyle karşılaştırılmasında ve benzerliklerin / farklılıklarının anlamlı bir şekilde gösterilmesinde kullanılmaktadır. LL analizlerinde bulunan anlamlı farkların etki büyüklüğünü ölçmek için de bu çalışmada Hardie's Log Ratio (HLR) yöntemi kullanılmaktadır.

\section{BULGULAR}

\section{Sözlükler}

Aşk Türkçe'de çok kullanılan sözcüklerden biri olmakla birlikte, köken olarak bakıldığında Eski Türkçe kökenli olmadığı görülmektedir. Aşk, Arapça'dan Türkçe'ye geçmiş bir sözcüktür. Diller arası ödünç alınan her sözcük gibi anlam genişlemesine, daralmasına ve kaymasına uğradığı için Arapça'daki aşk ile Türkçe'deki aşk tam tamına örtüşmemektedir. TDK'ya göre aşk, Türkçe'de "Aşırı sevgi ve bağlılık duygusu, sevi, sevda, amor" anlamına gelmektedir.

TDK'da aşkla ilgili çeşitli deyimler ve atasözleri verilmektedir. Bulunan deyimler:

1) Aşka düşmek yani aşık olmak.

2) Aşka gelmek yani bir şeyi yapmak için büyük bir istek duymak, coşmak, coşkunluk göstermek.

Bulunan tek atasözü ise:

3) Kumarda kaybeden aşkta kazanır yani halk arasındaki inanca göre kumar oynayan ve parasını kaybeden biri üzülmemelidir, böyleleri aşkta şanslıdırlar.

Aşağıda görüleceği gibi, TUD'dan ve Twitter'dan elde edilen veriler aşkın günlük dilde kullanımını ortaya çıkartarak, aşkın TDK'daki anlam ve kullanımlarından daha derin ve kapsamlı olduğuna işaret etmektedir.

\section{Sözcük Sıklıkları}

TUD'da 2,500 satır veride aşk sözcüğünün geçtiği ifadeler bulunup bunlardan bir derlem oluşturuldu. Bu derlemde 10,671 farklı sözcükten oluşan toplam 27,855 sözcük vard1. Farklı sözcük, sözcük oranı (FS/S) 383,091.0 olarak gerçekleşti (genel kabule uyarak, oran 1,000,000 ile çarpılmıştır). Twitter'dan elde edilen ve içinde aşk sözcügü̈nün geçtiği 85,980 twitte ise 130,016 farklı sözcükten oluşan toplam 1,280,736 sözcük 
vardı $(\mathrm{FS} / \mathrm{S}=101,516.62)$. Dolayısıyla, TUD verisinin sözcüksel dağılımının Twitter verisinden yüksek olduğu bulunmuştur.

Aşk ile birlikte en çok kullanılan sözcükler, beklenildiği üzere, her derlemde / metinde en sık kullanılan bir, ve, $b u$, $d a$, gibi, için, o, ne, çok, ben ve kadar gibi işlevsel sözcüklerdir. Aşk hariç, göreli entropi değerleri ise derlem için $\mathrm{H}_{\text {rel }}=0.60$, sosyal medya için $\mathrm{H}_{\text {rel }}=0.66$ olarak hesaplandı. Buna göre, sosyal medyadaki ilk 30 sözcügün kendi içerisinde dağılımı derlemdekinden biraz daha fazla homojendi.

Sıklıklara göre, işlevsel sözcüklerin yanı sıra ilk 30 sözcükte aşk haricinde iki içerik sözcüğü de bulundu (Bkz. Tablo 1). Bunlar, TUD’da sevgi ve Twitter'da acısı sözcükleridir. Dolayısıyla, bu iki sözcük aşk ifadelerine önemli ölçüde anlamsal katkıda bulunmaktadır. Bunlara ilaveten, sözcük türlerine göre aşkla birlikte en çok kullanılan adıllar ben ve sen; isimler sevgi, aşık, insan, sevda, zaman, eğlence, gerçek, ölüm, para, hayat, Allah, hikaye, şiir ve öykü iken; sıfatlar ise bir, bu, o, ne, çok, her, en, büyük, ilk ve yeni gibi sözcüklerdi. Sık kullanılan sıfatlar arası ve isimler arası tanınma hızları (log sıklık değerleri oranı) birbirine oldukça yakınd1. Örneğin, derlemde bir, gibiden 1.34 kez daha hızlı tanınırken, büyükten $1.63 \mathrm{kez}$ daha hızı tanınmaktaydı. Dolayısıyla bu sik kullanılan sözcüklerin aşk sözcüğ̈̈nün anlamına katkılarının birbirlerine yakın olduğu söylenebilir.

\section{Eşdizimli Sözcükler}

Bir sözcükten önce ve sonra kullanılan eşdizimli sözcükler de (İng. collocates) anlama katkıda bulunmaktadırlar. Bu nedenle aşk sözcüğünün bir öncesindeki / solundaki ile bir sonrasındaki / sağındaki sözcüklere $(\mathrm{N} \pm 1)$ ve iki öncesindeki ve iki sonrasındaki sözcüklere $(\mathrm{N} \pm 2)$ bakıldı. Bu aralıklarda yer alan sözcüklerin bir listesi çıkartıldı ve bu sözcüklerin bu aralık içinde ve dışında kullanımı MI istatistiği kullanarak karşılaştırıldı. Buna göre Tablo 1 ve Tablo 2'de verilen sözcükler aşk sözcüğü ile eşdizimli olup aşka istatistiksel olarak anlamlı katkısı bulundu.

MI’ya ilaveten, sözcüklerin birbirleriyle ilişkisini ve birbirine çekimini göstermek için $\Delta \mathrm{p}$ ve $\mathrm{G}$ değerlerini hesaplandı (Tablo 2 ve Tablo 3). Ancak, bu hesaplar için TUD'dan edinilen derlem verisi oldukça küçük kalmaktadır. Bu yüzden, sadece Twitter’dan edinilen sosyal medya verisini kullanıldı. $\mathrm{N} \pm 1$ 'de $\Delta \mathrm{p}$ değerlerine bakıldığında değerlerin +0.61 0.98 arasında olduğunu bulundu. Bu değerlerin pozitif olması ve maksimum değer olan 1.00'a yaklaşması bu sözcükler ile aşk arasındaki bağlantının güçlü olduğunu göstermektedir. 
Tablo 1. En Sık Rastlanılan Sözcüklerin Sıklıkları, Yüzdeleri ve Log Sıklıkları (En Sık 30 Sözcük)

\begin{tabular}{|c|c|c|c|c|c|c|c|}
\hline \multicolumn{4}{|c|}{ Derlem } & \multicolumn{4}{|c|}{ Sosyal Medya } \\
\hline Sözcük & Sıklık & Yüzde & Log sıklık & Sözcük & Sıklık & Yüzde & Log sıklık \\
\hline aşk & 2,750 & 9.87 & 7.91936 & aşk & 93,674 & 7.31 & 11.44758 \\
\hline bir & 966 & 3.47 & 6.87316 & bir & 26,150 & 2.04 & 10.17160 \\
\hline ve & 606 & 2.18 & 6.40688 & bu & 13,371 & 1.04 & 9.50084 \\
\hline $\mathrm{bu}$ & 343 & 1.23 & 5.83773 & ve & 11,687 & 0.91 & 9.36623 \\
\hline da & 249 & 0.89 & 5.51745 & ne & 9,127 & 0.71 & 9.11899 \\
\hline de & 210 & 0.75 & 5.34711 & da & 8,129 & 0.63 & 9.00319 \\
\hline gibi & 170 & 0.61 & 5.13580 & de & 7,816 & 0.61 & 8.96393 \\
\hline için & 161 & 0.58 & 5.08140 & ben & 6,833 & 0.53 & 8.82952 \\
\hline o & 151 & 0.54 & 5.01728 & için & 6,255 & 0.49 & 8.74114 \\
\hline ne & 136 & 0.49 & 4.91265 & acis1 & 5,929 & 0.46 & 8.68761 \\
\hline çok & 115 & 0.41 & 4.74493 & kadar & 5,731 & 0.45 & 8.65365 \\
\hline ile & 112 & 0.40 & 4.71850 & gibi & 5,706 & 0.45 & 8.64927 \\
\hline her & 106 & 0.38 & 4.66344 & o & 5,644 & 0.44 & 8.63835 \\
\hline ama & 92 & 0.33 & 4.52179 & çok & 5,288 & 0.41 & 8.57320 \\
\hline değil & 91 & 0.33 & 4.51086 & ki & 5,270 & 0.41 & 8.56979 \\
\hline en & 89 & 0.32 & 4.48864 & sen & 5,251 & 0.41 & 8.56617 \\
\hline ya & 86 & 0.31 & 4.45435 & var & 5,230 & 0.41 & 8.56217 \\
\hline daha & 80 & 0.29 & 4.38203 & ama & 5,124 & 0.40 & 8.54169 \\
\hline ki & 77 & 0.28 & 4.34381 & değil & 4,976 & 0.39 & 8.51238 \\
\hline kadar & 75 & 0.27 & 4.31749 & ile & 4,788 & 0.37 & 8.47387 \\
\hline zaman & 72 & 0.26 & 4.27667 & her & 4,747 & 0.37 & 8.46527 \\
\hline büyük & 67 & 0.24 & 4.20469 & ya & 4,521 & 0.35 & 8.41649 \\
\hline ben & 64 & 0.23 & 4.15888 & $\mathrm{~m} 1$ & 4,400 & 0.34 & 8.38936 \\
\hline sevgi & 62 & 0.22 & 4.12713 & olsun & 4,242 & 0.33 & 8.35279 \\
\hline var & 61 & 0.22 & 4.11087 & güzel & 4,022 & 0.31 & 8.29953 \\
\hline sonra & 56 & 0.20 & 4.02535 & yok & 3,978 & 0.31 & 8.28853 \\
\hline ilk & 54 & 0.19 & 3.98898 & en & 3,680 & 0.29 & 8.21067 \\
\hline hiç & 53 & 0.19 & 3.97029 & bi & 3,453 & 0.27 & 8.14700 \\
\hline yeni & 53 & 0.19 & 3.97029 & daha & 3,406 & 0.27 & 8.13329 \\
\hline $\mathrm{m} 1$ & 52 & 0.19 & 3.95124 & $\mathrm{mi}$ & 3,392 & 0.26 & 8.12917 \\
\hline
\end{tabular}

Sık kullanılan sözcükler arasındaki bağlantının sırasını göstermek için normal sıralamada / pozisyonda ve ters pozisyonda (örneğin, aşk acısı için $\mathrm{G}$, acısı aşk için $\mathrm{G}_{\text {ters }}$ ) sözcüksel çekim değerleri de hesaplandı. İşlevsel sözcükler olan nedir, ola gibi birkaç istisna hariç, $\mathrm{G}$ değerlerinin $\mathrm{G}_{\text {ters }}$ değerlerinden bir kaç kat yüksek oluşu, sözcük sıralarındaki çekimin daha yüksek olduğunu göstermektedir. Yani, aşktan sonra acısının gelmesi, aşkın acısıyı çekmesi, acısından sonra aşkın gelmesi yani acının aşkı çekmesinden 5.26 kat (=5.16/0.98) daha yüksektir. Bu analizler göstermektedir ki, aşk hikayesi / öyküsü / mektubu / şarkıları, aşk oyunları, aşk mecarası, aşk acısı / acıları, aşk üzerine, aşk hayatı / yaşamı, aşk nefret, aşk mezar ve sonsuz aşk, ilan-ı aşk, mecazi aşk, ilahi aşk, imkansız 
aşk, aşk meşk, kasımda aşk başkadır gibi eşdizimler sılklıkla ve anlamlı bir şekilde kullanılmaktadır. Dolayısıyla, bu sözcüklerin de aşkın anlamına katkısı bulunmuştur.

Tablo 2. Așk Sözcüğünden Bir Önce ve Bir Sonra Kullanılan Sözcükler (N \pm 1$)$

\begin{tabular}{|c|c|c|c|c|c|c|c|c|c|c|c|c|}
\hline \multicolumn{5}{|c|}{ Derlem } & \multicolumn{8}{|c|}{ Sosyal Medya } \\
\hline Pozisyon & Sözcük & MI & $\begin{array}{c}\text { Siklık } \\
(\geq 5)\end{array}$ & Lo & Pozi & Sözcük & MI & $\begin{array}{l}\text { Sıklık } \\
(\geq 200)\end{array}$ & $\begin{array}{c}\text { Log } \\
\text { slklık }\end{array}$ & $\Delta \mathbf{p}$ & $\mathbf{G}$ & Gters \\
\hline Sonra & hikâyesi & 3.11508 & 21 & 3.04452 & Sonra & ac1s1 & 3.64807 & 5,596 & 8.62981 & 0.90 & 5.16 & 0.98 \\
\hline Sonra & öyküsü & 3.10820 & 19 & 2.94444 & Sonra & nedir & 3.21672 & 1,077 & 6.98193 & 0.68 & 4.46 & 3.05 \\
\hline Sonra & üstüne & 3.00163 & 15 & 2.70805 & Önce & kasımda & 3.56484 & 834 & 6.72623 & 0.88 & 4.07 & 0.19 \\
\hline Sonra & mektubu & 3.28911 & 14 & 2.63906 & Sonra & hikayesi & 3.61946 & 737 & 6.60259 & 0.90 & 3.71 & 0.96 \\
\hline Sonra & ac1s1 & 3.04470 & 10 & 2.30259 & Sonra & başkadır & 3.55724 & 705 & 6.55820 & 0.81 & 3.62 & 0.41 \\
\hline onra & hikâyesini & 3.18220 & 9 & 2.19722 & Sonra & yaşıyorum & 3.50003 & 610 & 6.41346 & 0.81 & 3.75 & 1.77 \\
\hline onra & yaşamadım & 3.37484 & 8 & 2.07944 & Sonra & meşk & 3.44961 & 518 & 6.24998 & 0.81 & 3.54 & - \\
\hline Ónce & sonsuz & 3.18220 & 8 & 2.07944 & Sonra & acisinı & 3.40201 & 490 & 6.19441 & 0.79 & 3.63 & -0.29 \\
\hline Önce & ilan-1 & 3.18220 & 8 & 2.07944 & Sonra & mezara & 3.59149 & 474 & 6.16121 & 0.91 & 3.13 & - \\
\hline Sonra & romanlarının & 3.18220 & 7 & 1.94591 & Sonra & dediğin & 3.39518 & 467 & 6.14633 & 0.78 & 3.63 & 0.78 \\
\hline Sonra & hikayesini & 3.18220 & 7 & 1.94591 & Önce & zorgünler & 3.23743 & 455 & 6.12030 & 0.71 & 3.91 & - \\
\hline Sonra & hikayesi & 3.18220 & 7 & 1.94591 & Sonra & ac1lı & 3.56227 & 318 & 5.76205 & 0.89 & 3.24 & 1.08 \\
\hline Sonra & acıları & 3.40459 & 7 & 1.94591 & Sonra & acisindan & 3.64470 & 314 & 5.74939 & 0.94 & 2.67 & -0.31 \\
\hline Sonra & şarkıları & 3.18220 & 6 & 1.79176 & Sonra & bitsin & 3.49994 & 296 & 5.69036 & 0.84 & 3.12 & 0.53 \\
\hline onra & yaşar & 3.18220 & 6 & 9176 & Önce & yasak & 3.41794 & 295 & 5.68698 & 0.80 & 3.49 & - \\
\hline onra & tanris1 & 3.18220 & 6 & 1.79176 & Sonra & misin & 3.26901 & 277 & 5.62402 & 0.72 & 3.68 & 3.36 \\
\hline Önce & mecazî & 3.18220 & 6 & 1.79176 & Sonra & hayatım & 3.02551 & 266 & 5.58350 & 0.61 & 3.34 & 1.88 \\
\hline Önce & imkansız & 3.44523 & 6 & 1.79176 & Sonra & nefrete & 3.15863 & 262 & 5.56834 & 0.67 & 2.86 & -0.11 \\
\hline Önce & ilahi & 3.18220 & 6 & 1.79176 & Sonra & onunla & 3.03324 & 234 & 5.45532 & 0.61 & 3.33 & 1.24 \\
\hline Sonra & hikâyeleri & 3.18220 & 6 & 1.79176 & Sonra & onda & 3.09709 & 231 & 5.44242 & 0.64 & 3.10 & -0.15 \\
\hline Sonra & hikayesiydi & 3.44523 & 6 & 1.79176 & Sonra & şarab1 & 3.65714 & 228 & 5.42935 & 0.95 & 2.57 & -1.29 \\
\hline Sonra & büyüleri & 3.76716 & 6 & 1.79176 & Önce & sesinde & 3.64118 & 217 & 5.37990 & 0.93 & 2.78 & - \\
\hline Sonra & şiirlerinin & 3.18220 & 5 & 1.60944 & Sonra & ola & 3.49032 & 215 & 5.37064 & 0.78 & 3.00 & 2.24 \\
\hline Sonra & oyunlarına & 3.18220 & 5 & 1.60944 & Önce & ilanı & 3.71820 & 208 & 5.33754 & 0.98 & 3.95 & 1.40 \\
\hline Sonra & macerası & 3.18220 & 5 & 1.60944 & Sonra & şark1s1 & 3.09331 & 202 & 5.30827 & 0.64 & 3.15 & 1.04 \\
\hline Sonra & derecesinde & 3.18220 & 5 & 1.60944 & & & & & & & & \\
\hline Sonra & denilen & 3.18220 & 5 & 1.60944 & & & & & & & & \\
\hline
\end{tabular}

\section{Çok Sözcüklü Birimler}

Bazı eşdizimli sözcükler kalıp ifadelere dönüşerek yapısal olarak anlama katkıda bulunmaktadırlar. $A s ̧ k$ verilerindeki çok sözcüklü birimler (İng. n-grams) incelendiğinde Tablo 4'teki birimler ve bu birimlerle birlikte hareket eden sözcükler bulundu. Bu birimler genelde ve, bir gibi işlevsel sözcüklerden oluştuğu için $\Delta \mathrm{p}$ değerleri düşük olarak bulundu (çünkü, işlevsel sözcükler başka sözcüklerle de beraber hareket ettikleri için aşk ile $\Delta \mathrm{p}$ değerleri düşmektedir). Diğer birimlerin $\mathrm{G}$ sözcüksel çekim değerleri ise yukarıda Tablo 2'de verilen eşdizimli sözcükler kadar yüksek çıktı. Dolayısıyla, birimlerin 
kalıp ifadeler halinde yer aldığı, günlük dilde sıklıkla kullanıldığı ve aşkın anlamına katkı sağladığı bulunmuştur.

Tablo 3. Aşk Sözcüğünden İki Önce ve İki Sonra Kullanılan Sözcükler (N \pm 2$)$

\begin{tabular}{lccccccccc}
\hline & \multicolumn{3}{c}{ Derlem } & \multicolumn{3}{c}{ S } & \multicolumn{5}{c}{ Sosyal Medya } \\
\hline Pozisyon & Sözcük & MI & $\begin{array}{c}\text { Sıklık } \\
\mathbf{( \geq 1 0 )}\end{array}$ & Log sıklık & Pozisyon & Sözcük & MI & $\begin{array}{c}\text { Sıklık } \\
\mathbf{( \geq 5 0 0 )}\end{array}$ & Log sıklık \\
\hline Sonra & olsun & 3.0235 & 43 & 3.76120 & Sonra & acısı & 3.67514 & 5,702 & 8.64857 \\
Sonra & üstüne & 3.6797 & 24 & 3.17805 & Sonra & nedir & 3.48599 & 1,298 & 7.16858 \\
Sonra & hikâyesi & 3.1151 & 21 & 3.04452 & Önce & gerçek & 3.11651 & 928 & 6.83303 \\
Sonra & öyküsü & 3.1082 & 19 & 2.94444 & Önce & kasımda & 3.66506 & 894 & 6.79571 \\
Sonra & mektubu & 3.4818 & 16 & 2.77259 & Sonra & başkadır & 3.70679 & 782 & 6.66185 \\
Sonra & şiirleri & 3.0753 & 13 & 2.56495 & Sonra & hikayesi & 3.65045 & 753 & 6.62407 \\
Sonra & acısı & 3.4232 & 13 & 2.56495 & Önce & para & 3.09098 & 721 & 6.58064 \\
Önce & platonik & 3.0667 & 12 & 2.48491 & Sonra & yaşıyorum & 3.61805 & 662 & 6.49527 \\
Sonra & yaşamadım & 3.6968 & 10 & 2.30259 & Sonra & biter & 3.12099 & 623 & 6.43455 \\
Önce & sonsuz & 3.5041 & 10 & 2.30259 & Sonra & meşk & 3.64712 & 594 & 6.38688 \\
Sonra & budur & 3.1822 & 10 & 2.30259 & Önce & adı & 3.07161 & 548 & 6.30628 \\
& & & & & Sonra & mezara & 3.76615 & 535 & 6.28227 \\
& & & & & Sonra & acısını & 3.43979 & 503 & 6.22059 \\
\hline
\end{tabular}

Tablo 4. Çok Sözcüklü Birimler ve Sıklık, $\Delta \mathrm{p}$ ve G Değerleri

\begin{tabular}{lccc}
\hline & Sıklık & $\mathbf{\Delta p}$ & $\mathbf{G}$ \\
\hline aşk olsun & 1,552 & 0.38 & 4.81 \\
aşk ile & 1,993 & 0.41 & 5.23 \\
aşk gibi & 636 & 0.11 & 4.29 \\
aşk için & 1,125 & 0.17 & 4.65 \\
aşk da & 410 & 0.05 & 3.85 \\
aşk ve & 1,761 & 0.14 & 5.28 \\
ve aşk & 864 & 0.07 & 4.80 \\
bir aşk & 3,935 & 0.12 & 5.99 \\
aşk bir & 1,521 & 0.05 & 4.95 \\
\hline
\end{tabular}

Bu birimlerden aşk olsun deyimsel / donmuş bir ifade olarak ortaya çıktı. Aşk olsun... kalıbı daha çok ünlem biçiminde kullanılmaktaydı ve anlamı aşkın temel anlamlarından daha uzak olup, genellikle serzeniş ifade etmekteydi. Örneğin, aşk olsun; aşk olsun sana; aşk olsun be candaş; aşk olsun yani. Bu donmuş ifadenin yanı sıra belirgin çok sözcüklü birimler arasında $a s ̧ k$ (, ) bir ..., aşk ve .../...ve aşk, aşk da ..., aşk için ..., aşk gibi..., aşk ile... gibi birimler yer almaktayd.

Çok sözcüklü birimlerden $a s ̧ k$, bir ... bir tanımlama ifadesi olup bu birimle aşkın tanımları, başka sözcüklerle bağlantıları, benzetmeleri ve metaforik kullanımları da bu- 
lundu. Örneğin, aşk başkasına duyulan cinsel istekle ve arınma duygusu ile tanımlanabilmekte; suya, ateşe, şimşeğe ve yıldırıma benzetilmekte; ve süre olarak çok kısa, örneğin bir gece, sürebilmektedir. Aşk bir ... birimi de bu tanımları, aşkın başka sözcüklerle bağlantılarını, benzetmelerini ve metaforik kullanımlarını daha da genişletti. Öyle ki, aşk hastalık veya dengesizlik olarak tanımlanabilmekte; yük ve hamallık olarak düşünülmekte; ve geçmişteki bir hatıra gibi ifade edilebilmektedir. ... bir aşk birimi ise aşkın ne şekillerde olabileceğini gösteren bir ifadeydi. Aşk yeni veya başka bir aşk olabileceği gibi, büyük bir aşk olabilir; gerçek veya platonik bir aşk olabilir; ve kırık bir aşk da olabilir.

Bir eşuyum kalıbı olan aşk ve.../...ve aşk birimi ise aşk ile beraber olabilecek şey ve eylemleri işaret etmekteydi. Örneğin, aşk, sevgi / sevda / eğlence / tutku / haz / gurur ile bir arada olabilir. Ancak, aşk ile hüzün / yalnızlık / nefret de gelebilir. Aşk, barışta da savaşta da olabilir. Aşk da... birimi bir ekleme ifadesi olup aşk da yok, aşk da bitti ile aşk da öyle, aşk da böyle (bir şey) gibi kullanılmaktadır. Amaç belirten aşk için ... birimi, daha çok olumsuz ifadelerde kullanılan, aşkın riskli bir eylem olduğunu işaret eden bir ifade şekli olarak bulundu. Bir şarkı sözünde de geçtiği gibi aşk için ölmeli, aşk o zaman aşk ifadesinin yanı sıra aşk için acı çekilir; aşk için sana yalan söyledim; aşk için mücadele etmeli; aşk için ısrarcı (olma). Çok kullanılan kalıplardan bir tanesi de, bir benzetme ifadesi olan aşk gibi... birimiydi. Bu birimle inanç, yüce, ömür, sevda, şehvet gibi sözcükler aşka benzetilmekteydi. Ayrıca, aşk ile ... biriminin pek çok kullanımı olmakla birlikte eşuyum ifadeleri aşk ile nefret / sevgi; tarz ifadeleri aşk ile yap(an) / çallşan / yürüyen / koşan s1klıkla gözlemlendi.

\section{İlkörneklerle Anlam Bağlantıları}

Aşk sözcüğü ile birlikte sıklıkla kullanılan sözcükler, eşdizimli sözcükler ve çok sözcüklü birimleri birlikte analiz edilerek aşkın anlam bağlantıları (İng. semantic associations) çıkartıldı. Bulgulara göre aşk, NİTELIK, NİCELIK, ZAMAN, YER, GERÇEKLİK, ZİHIN, BEDEN, DİL, İNANÇ, ŞEY, KIŞİ, BİTKİ ve TAŞIT ilkörnekleriyle bağlantılı bir kavram olup bunlarla sıklıkla kullanılmaktadır. Aşkla birlikte NİTELİK ilkörneğinden böyle, bu, büyük, derin, gizli gibi sıfatlar kullanılmaktadır. Örneğin, gizli aşk, güzel aşk, içten bir aşk, imkansız aşk, yasak aşk tamlamalarında olduğu gibi. Aşkla birlikte NíCELİK için bir, bir çeşit, çok gibi sıfatlar kullanılmaktadır. Örneğin, bir tek aşk, ikinci aşk, tek aşk tamlamalarında olduğu gibi. Ayrıca, aşk sıfat olarak aşk çeşidi, aşk derecesi, aşk türü gibi nicelik ve nitelik açısından belirtilmektedir. 
Aşk, ZAMAN ilkörneği ile de bağlantılıdır. Çünkü aşk kavramı ile ilk, eski, ebedi, saat, mevsim, zaman gibi zaman belirten kavramlar birlikte kullanılmaktadır. Örneğin, bir gecelik aşk, ezeli aşk, sonsuz aşk, aş̧ gecesi, aşk hayatı, aşk iklimleri gibi. Aşk, ZAMAN ilkörneği ile bağlantılı olduğu gibi YER ilkörneği ile de bağlantılıdır. Çünkü, bu kıtalararası aşk, dünyevi aşk, şehrinizin göbeğindeki aşk, aşk mutfağı, aşk pınarı, aşk adası örneklerinde görüldüğü gibi aşk dünya, kıta, şehir, gezegen, ev, mekan, çeşme gibi sözcüklerle birlikte kullanılabilmektedir. Aşk, doğru, gerçek gibi sözcüklerle birlikte kullanıldığı için GERÇEKLİK ilkörneği ile de bağlantılıdır. Örneğin, aşk mecazi aşk ya da hayali aşk olabileceği gibi gerçek bir aşk da olabilir.

Aşk, bilgi, cinnet, paranoya, romantik, nörolojik gibi sözcüklerle birlikte de kullanılmaktadır. Verilerde, romantik bir aşk, nörolojik bir aşk, aşk psikolojisi, aşk sarhoşlu$\breve{g} u$, aşk anlayışı gibi ifadeler de görülmektedir. Bu nedenle, aşk, ZİHİN ilkörneği ile de bağlantılıdır. Aşk, ZİHIN ilkörneği ile bağlantılı olduğu gibi BEDEN ilkörneği ile de bağlantılıdır. Bedenle ilgili $a c ı$, çürük, kanat, gövde gibi ifadeler aşk sözcüğü ile beraber gözlemlenebilmektedir. Örneğin, kör aşk, acılara batmamış bir aşk, aşk acısı çekmek, aşk kanatları, aşk öpücükleri, aşk yarası tamlamalarında olduğu gibi.

Aşk, söz, anlatım, öykü, kitap gibi sözcüklerle birlikte bulunabildiği için DİL ilkörneği ile de bağlantılıdır. Örneğin, ilan-ı aşk, masalsı aşk, aşk sözcükleri, aşk şiiri, aşk mektubu, aşk fisıltıları gibi tamlamalar sıklıkla veride yer almaktadır. Bulgulara göre, aşk, İNANÇ ilkörneği ile de bağlantılıdır. İlahi aşk, mukaddes aşk, aşk dini, aşk ilahesi, aşk tanrısı, aşk tanrıçası tamlamalarında görüldüğü gibi aşk, İNANÇ kategorisinden ilahi, mukaddes, din, ilahe, tanrı(ça) gibi sözcüklerle birlikte kullanılmaktadır.

Bunlara ilaveten, aşk, ŞEY, KİŞİ, BİTKİ, TAŞIT gibi ilkörneklerle de bağlantılıdır. Aşk, alev, ateş, bela, büyü, meltem gibi ŞEYlerle birlikte kullanılmaktadır. Örneğin, aşk mızrağı, aşk kıvılcımları, aşk serüveni gibi. Aşk, kadın, insan, profesör gibi Kişi̇lerle birlikte kullanılmaktadır. Örneğin, aşk kadını, aşk şairi, aşk profesörü, aşk çocuğu gibi. Aşk, aynı zamanda aşk meyvesi, aşk yaprakları gibi kullanımlarda olduğu gibi BİTKİ ifadeleriyle de birlikte gözlemlenebilmektedir. Aşk, aynı zamanda TAŞITlarla birlikte kullanılmaktadır. Örneğin, aşk treni, aşk gemisi tamlamalarında olduğu gibi.

\section{Tür Karşılaştırmaları}

Farklı kaynaklardan edinilen veriler farklı anlamları oluşturabilmektedirler. Kullanılan veri kaynağını oluşturan türlere göre de (İng. genre) farklı anlam bağlantıları oluşabilmektedir. Bu nedenle derlem verisiyle sosyal medya verisi karşılaştırıldı. 
TUD verisinde yer alan bazı sözcüklerin sıklıkları Twitter verisindeki aynı sözcüklerin sıklıklarından anlamlı bir şekilde fazlaydı (Bkz. Tablo 5). Bu sözcükler arasında hikaye, öykü, roman, şiir, mektup gibi edebi eserlerle ilgili sözcükler oldukça dikkat çekiciydi. Örneğin, (aşk) romanı (sıklık = 14, LL = 38.59, $p<.0001$, HLR = 3.4234) ifadesi TUD'da anlamlı bir şekilde $10.7 \mathrm{kez}\left(=2^{3.4234}\right)$ daha fazla kullanılmıştı. Buna ilaveten, aşkla ilgili eğlence, şevk, ümit gibi pozitif ifadeler de TUD'da anlamlı bir şekilde daha sık kullanılıyordu. Örneğin, (aşk bir) e ğlence ( 1 1kl1k $=25, \mathrm{LL}=96.21, p$ $<.0001$, HLR $=4.4119)$ ifadesi TUD'da anlamlı bir şekilde $21.3 \mathrm{kez}\left(=2^{4.4119}\right)$ daha fazla kullanılmıştı. Ayrıca, aşk ile evlilik, çocuklar gibi aileyi çağrıştıran ifadeler de

Tablo 5. Türkçe Ulusal Derlem Verisinde Twitter Verisinden Anlamlı Bir Şekilde Daha Sık Kullanılan Sözcükler (LL $\geq 15.03, p<.0001$, HLR $\geq 2$ etki büyüklüğ̈̈)

\begin{tabular}{|c|c|c|c|}
\hline Sözcük & Sıklık & $\mathbf{L L}$ & Etki büyüklüğü \\
\hline üzerine & 41 & 83.43 & 2.7719 \\
\hline ancak & 27 & 35.88 & 2.1029 \\
\hline eğlence & 25 & 96.21 & 4.4119 \\
\hline hikâyesi & 23 & 81.71 & 4.1396 \\
\hline âşık & 21 & 49.90 & 3.0823 \\
\hline yalnızca & 21 & 36.69 & 2.5058 \\
\hline öyküsü & 20 & 61.66 & 3.7155 \\
\hline evlilik & 20 & 26.45 & 2.0966 \\
\hline şiiri & 19 & 31.50 & 2.4221 \\
\hline adli & 18 & 54.15 & 3.6484 \\
\hline konusunda & 18 & 31.01 & 2.4834 \\
\hline ümit & 16 & 26.40 & 2.4144 \\
\hline ilişkisi & 15 & 36.07 & 3.1079 \\
\hline romanı & 14 & 38.59 & 3.4234 \\
\hline üzerinde & 14 & 31.84 & 2.9904 \\
\hline şiirleri & 14 & 29.01 & 2.8067 \\
\hline romanları & 13 & 63.31 & 5.416 \\
\hline mektupları & 13 & 48.02 & 4.2691 \\
\hline ilişkileri & 13 & 44.38 & 4.0139 \\
\hline yazdığ 1 & 13 & 35.36 & 3.3904 \\
\hline mektubu & 13 & 22.19 & 2.4684 \\
\hline cinsellik & 12 & 40.50 & 3.9786 \\
\hline anlatan & 12 & 26.07 & 2.8984 \\
\hline şevk & 12 & 22.59 & 2.6321 \\
\hline çocuklar & 12 & 21.77 & 2.5687 \\
\hline şiirde & 11 & 51.00 & 5.175 \\
\hline üstelik & 11 & 32.80 & 3.6248 \\
\hline miydi & 11 & 22.39 & 2.7729 \\
\hline venüs & 10 & 35.58 & 4.1444 \\
\hline dönem & 10 & 29.09 & 3.5594 \\
\hline duyduğu & 10 & 26.42 & 3.3213 \\
\hline
\end{tabular}


TUD'da Twitter'dan daha fazla kullanılmıştı. Örneğin, (aşk ve) evlilik (sıklık = 20, $\mathrm{LL}=26.45, p<.0001, \mathrm{HLR}=2.0966)$ ifadesi TUD'da anlamlı bir şekilde $4.3 \mathrm{kez}(=$ $2^{2.0966)}$ daha fazla kullanılmıştı.

Twitter verisiyle TUD verisini karşılaştırıldığında da Twitter verisinde yer alan bazı sözcüklerin sıklıklarının TUD verisindeki aynı sözcüklerin sıklıklarından anlamlı bir şekilde fazla olduğu bulundu (Tablo 6). Twitter'da aşk, sen, seni gibi adıllarla, escort, bayan gibi isimlerle ve Beşiktaş (spor kulübü) gibi grup isimleriyle TUD’a göre nesnesi belli bir şekilde daha dinamik olarak anlamlandırılıyordu. Örneğin, sen (sıklık $=5.221$, $\mathrm{LL}=101.24, p<.0001, \mathrm{LHR}=2.1916)$ ifadesi Twitter'da anlamlı bir şekilde $4.57 \mathrm{kez}$ $\left(=2^{2.1916}\right)$ daha fazla kullanılmıştı. Twitter'da acısı, zor günler gibi ifadeler TUD'dan daha fazla kullanılıyordu, dolayısıyla, Twitter'da aşk daha negatif anlamlandırılmıştı. Örneğin, acısl (sıklık = 5.929, LL = 179.93, $p<.0001$, HLR = 3.5512) ifadesi Twitter'da anlamlı bir şekilde $11.7 \mathrm{kez}\left(=2^{2.1916}\right)$ daha fazla kullanılmıştı. Twitter'da bayan, escort, elden, ödeme gibi sözcüklerle aşk para karşılığ yapılan bir eylem olarak daha s1k gözlemlendi. Örneğin, (elden) ödeme (sıklık $=1.095, \mathrm{LL}=47.14, p<.0001$, HLR $=$ $5.5738)$ ifadesi Twitter'da anlamlı bir şekilde $47.6 \mathrm{kez}\left(=2^{2.1916}\right)$ daha fazla kullanılmıştı. Twitter'da aşk, ayrıca kasımda (aşk başkadır [2001 tarihli Sweet November isimli sine-

Tablo 6. Twitter Verisinde Türkçe Ulusal Derlem Verisinden Anlamlı Bir Şekilde Daha Sık Kullanılan Sözcükler (LL $\geq 15.03, p<.0001, H L R \geq 2$ etki büyüklüğü)

\begin{tabular}{lccc}
\hline Sözcük & Sıklık & LL & Etki büyüklüğü \\
\hline acısı & 5,929 & 179.93 & 3.5512 \\
sen & 5,251 & 101.24 & 2.1916 \\
bi & 3,453 & 130.36 & 5.2307 \\
seni & 3,239 & 66.79 & 2.3311 \\
aşık & 2,117 & 40.99 & 2.2030 \\
elden & 1,605 & 53.75 & 4.1255 \\
kasım & 1,136 & 34.93 & 3.6269 \\
ödeme & 1,095 & 47.14 & 5.5738 \\
escort & 1,030 & 44.34 & 5.4855 \\
aracılığıla & 1,000 & 43.05 & 5.4429 \\
kalp & 964 & 41.50 & 5.3900 \\
kasımda & 940 & 40.46 & 5.3536 \\
kim & 787 & 26.24 & 4.0973 \\
çalışıyoruz & 717 & 30.86 & 4.9629 \\
günaydın & 679 & 29.23 & 4.8844 \\
beşiktaş & 647 & 27.85 & 4.8147 \\
zorgünler & 638 & 27.46 & 4.7945 \\
bayan & 610 & 26.26 & 4.7298 \\
\hline
\end{tabular}


ma filminin Türkçe ismi kalıp olarak dile yerleşmiş]) gibi kalıp ifadelerle de anlamlı bir şekilde daha fazla gözlemlendi. Bu bulgular göstermektedir ki, aşk, TUD’da daha edebiyken Twitter'da daha dinamik; TUD'da daha pozitifken Twitter'da daha negatif; TUD'da daha ailevi iken Twitter'da daha aile-dışıydı.

Bütün bulgular birleştirildiğinde şematik olarak aşkın ilkörneği şu şekildedir (Bkz. Şekil 1). Buna göre, aşkın üst kategorilerini NITELİK, NİCELIK, ZAMAN, YER, GERÇEKLIK, ZİHIN, BEDEN, DİL, İNANÇ, ŞEY, KİŞİ, BİTKİ, TAŞIT ... oluşturmaktadır. $\mathrm{Bu}$ üst kategorilerle ilgili olarak aşk sözcüğünden önce sonsuz, ilan, yasak, ses, mecazi, gerçek, platonik ... sonra ise acı, hikaye, öykü, mektup, şarkı, tanrı, meşk, şarap, hayat / yaşam, nefret, mezar ... gibi sözcükler sıklıkla yer almaktadır. Ayrıca, aşk bir..., aşk ve..., aşk ile... gibi çok sözcüklü birimler ve aşk olsun ve kasımda aşk başkadır gibi donuk ifadeler de aşkın ilkörneğini zenginleştirmektedir.

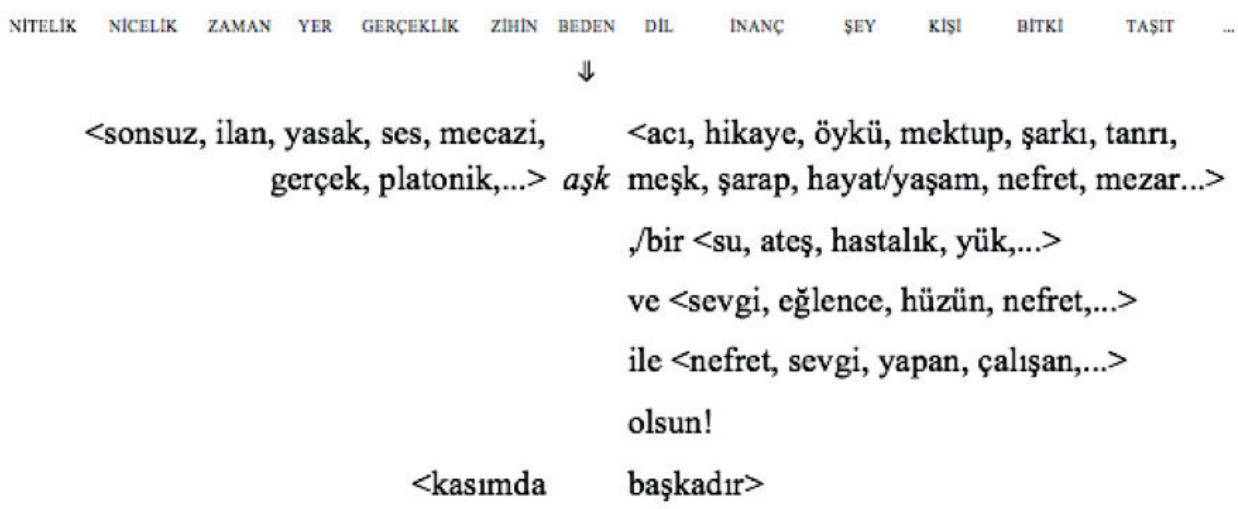

Şekil 1. Aşkın ilkörneği.

Not: aşk olsun! şikayet amacıyla ve/ya hayal kırıklığı belirtmek için kullanılan bir deyimdir. Kasımda Aşk Başkadır ise 2001 yılında gösterime giren bir filmin (İng. Sweet November) başlı̆̆ıdır.

\section{TARTIŞMA}

Bu çalışmada aşkın yazılı ve günlük dilde kullanımlarına odaklanılarak aşk kavramı tanımlanmaya çalışıldı. Derlem ve sosyal medyadan elde edilen Büyük Veri analizleri aşk kavramının resmi ve günlük dilde kullanımlarını ortaya koydu. Bu analizler sonucunda kapsamlı ve geliştirilmeye açık bir aşk ilkörneği çıkartıldı. 
Bulgular göstermektedir ki, aşkın sözlüksel anlamı ile dilde kullanımı arasında farkl1lıklar mevcuttur. Örneğin, TDK'daki aşk tanımında yer alan sevgi kavramı derlem ve sosyal medya verisinde sıklıkla kullanılmaktayken, sevi, sevda, amor gibi kavramlar verilerde nadiren kullanılmıştır. Ayrıca, TDK deyimler ve atasözleri sözlüklerinde yer alan aşka düşmek, kumarda kaybeden aşkta kazanır gibi ifadeler verilerde pek gözlenmemiştir.

Bulgulara göre, aşk kavramı sadece pozitif duygu ifadelerinde kullanılmamaktadır. İlkörnek kuramına göre aşk duyguların bir alt kategorisi olup mutlulukla aynı seviyede pozitif bir duygu kategorisidir (Shaver ve ark., 1987 vb.). Ancak, derlemden ve sosyal medyadan toplanılan Türkçe veriler bu savı kısmen desteklemektedir. Aşkla birlikte sık kullanılan ve duygu ve hisleri yansıtan sözcüklere ve kullanımlara bakıldığında aşkın hem pozitif (örn., tutkulu aşk) hem negatif deneyimlerle (örn., aşk acısı, aşk yarası) ilişkili olduğu bulunmuştur.

İlkörnek kuramında aşk POZİTİF DUYGUların bir alt kategorisi olarak belirtilmektedir. Bu çalışmanın bulgularına göre, aşk hem pozitif hem negatif duygularla ilişkili olmakla birlikte çeşitli ifade ve benzetmelerle NITELİK, NİCELİK, ZAMAN, YER, GERÇEKLİK, ZİHIN, BEDEN, DİL, İNANÇ, ŞEY, KIŞİ, BİTKİ, TAŞIT gibi daha karmaş1k üst kategorilere sahiptir. Örneğin, aşk treni ifadesinde aşk duygudan öte ZAMAN, YER, TAŞIT üst kategorileri ile daha sıkı bir ilişki içerisindedir. Benzer bir şekilde, aşk hayatı ifadesinde de duygudan ziyade ZAMAN üst kategorisi; ilahi aşk ifadesinde de duygudan ziyade İNANÇ üst kategorisi daha önceliklidir.

Alan yazında aşk çeşitleri sunulurken başka bir kişiye duyulan hisler (Murstein, 1988), yakın ilişki / samimiyet, tutku ve bağlılıkla olan yakın ilişkiler (Sternberg, 2006), duygusal deneyimlerin yaşandığı tutkulu durum veya güven, saygı ve arkadaşlık ile birlikte bir çeşit oyun (Lee, 1988) verilirken, bunlarla birlikte bağlanma, birbirine özen gösterme ve cinsel ilişkiden bahsedilmektedir (Shaver ve ark., 1996). Bu çalışmanın bulguları da alan yazını desteklemektedir. Bunlara ilaveten, bulgulara göre, aşk nefreti ve hüznü, kısa süreli (bir gecelik) ve parayla yapılan bağlanmasız (elden ödeme, bayan, escort) cinsel ilişkileri de kapsamaktadır. Ayrıca, aşkın nesnesi ya da aşkın her iki tarafı da insan olmak zorunda değildir; kişi bir gruba (örn., Beşiktaş spor kulübü) da aşık olabilir. Aynı zamanda aşk gerçek bir bağlanmayı da içermeyebilir (mecazi / platonik aşk gibi). 
Aşkın anlamı aynı zamanda bağlama ve dilin resmi ve gündelik kullanımlarına göre de çeşitlilik göstermektedir. TUD verisi Twitter verisinden daha çok farklı sözcük içermektedir. Bunun iki nedeni olabilir: Birincisi, TUD verisi edebi kaynaklardan da dahil olmak üzere dokuz farklı kaynaktan oluşurken, Twitter verisi sadece Twitter kullanıcılarının günlük twitlerinden oluşmaktadır. İkincisi, alan yazında da pek çok kez gözlemlenildiği gibi, veri arttıkça FS/S oranı düşmektedir. Twitter verisi TUD verisinden bir kaç kat daha büyük olduğu için, Twitter verisinde farklı sözcük oranı düşük çıkmaktadır. Bununla birlikte, derlem verisinde pozitif kullanımlar sosyal medya verisindeki pozitif kullanımlardan daha çok iken, negatif kullanımlar bunun tam tersidir. Aşk romanları gibi edebi ifadelerin derlemde kullanımı sosyal medyada kullanımından daha çoktur. Aynı şekilde, aşk çocuğu gibi aileyi çağrıştıran ifadelerin derlemde kullanımı sosyal medyada kullanımından daha çoktur. Ancak, escort, ödeme gibi aile-dışı aşkı çağrıştıran ifadeler ise bunun tam tersidir.

Türkçe'de aşk ve dil üzerine daha önce yapılan araştırmalar aşkın metaforik kullanımlarına odaklanmıştır (örn., Aksan ve Kantar, 2008a; Baş, 2015). Aksan ve Kantar'ın çalışmalarında (2008a, 2008b) Türkçe'de öne çıkan metaforlar arasında YOLCULUK, ÇİLE, ANLATILAMAMAZLIK, ÖLÜMCÜL gibi metaforlar yer almaktadır. Bu çalışmanın bulgularında da benzer metaforlar yer almaktadır. Bu çalışmada önerilen BEDEN, DİL, İNANÇ, TAŞIT gibi bu metaforlarla ilişkilendirilebilir. Örneğin, acı, hüzün, nefret, yük gibi ifadeler AŞK ÇİLE ÇEKMEKTİR metaforuyla da ilişkilidir. Hayat, yaşam, mezar gibi ifadeler AŞK ÖLÜMCÜL BİR GÜÇTÜR metaforuyla ilişkilendirilebilinir. Bunlarla birlikte, DOĞA GÜCÜ (örn., aşk meltemi), KENDİNDEN GEÇME (örn., aşk sarhoşluğu), SİHİR (örn., aşk büyüsü) gibi metaforlar derlem ve sosyal medya verisinde mevcuttur. Bu çalışmayla aşk metaforlarına ilaveten aşkın anlamına doğrudan etkisi olan sözcükler ve ifadeler de ortaya çıkartılarak aşkın ilkörneği çıkartılmıştır.

Bulgular göstermektedir ki, resmi ve ticari sözlüklerde aşk kavramı tanımlanırken kullanılan ifadeler resmi ve günlük dil kullanımlarıyla tam olarak örtüşmemektedir. $\mathrm{Bu}$ nedenle, aşk kavramının sözlüksel tanımlarında günlük dil kullanımlarına yer verilmeli ve bu sözcüğün zaman içerisindeki değişimi gözönüne alınmalıdır. Aynı zamanda, derlem dilbilim araştırmalarının kullanım yöntemlerinden birisi sözlük çalışmaları olduğu için (İng. lexicography, örneğin Sinclair, Collins COBUILD İngilizce sözlüklerinin editörüdür [2000]), Türkçe üzerine hem günlük kullanım hem de ikinci dil olarak öğrenme amaçlı sözlüklerde büyük veriden yararlanmak faydalı olacaktır. 
Ayrıca, bulgulara göre, aşk, sevgi, bağlanma ve yakın ilişkiler gibi konuları bilimsel olarak inceleyen çalışmalardaki aşk ve aşkla ilgili kavramlar, bu kavramların günlük dil kullanımlarıyla farklılaşmaktadır. Bu nedenle, hem gözlem / görüşme yapılan çalışmalarda hem de deneysel çalışmalarda bu kavramların kullanımına dikkat etmek gerekmektedir. Aşk gibi kavramlar sadece sözlüklere bağlı olarak tanımlandığında katılımcıların zihinlerindeki ve günlük dillerindeki karşılıklarıyla tam örtüşmemektedir. Aynı şekilde, çalışma alanlarına özel tanımlar ile katılımcıların tanımları arasındaki farklılıklar dikkate alınmalıdır. Kavramların ölçülebilir hale getirilmesiyle oluşturulan ölçüm araçlarıyla kullanılan araştırmalarda ölçülen şeyler ve bu kavramların günlük dildeki karşılıklarının tam örtüşmemesinin araştırma sonuçlarını etkileyebileceği göz ardı edilmemelidir.

\section{Araştırmanın Sınırlılıkları}

Bu çalışmanın çeşitli kısıtlılıkları vardır. Birincisi, bu çalışmada sadece aşk sözcüğüne odaklanıldı ama aşk sözcüğü başsözcük (İng. lemma) olarak düşünülmedi. Oysa, aşk sözcüğünün $a s ̧ ı k$, aşkı, aşklar, aşksız gibi çeşitli çekimli halleri aşk kavramının günlük dildeki kullanımını daha da genişletmekte ve/ya daraltmaktadır. İkincisi, bu çalışmada aşk sözcüğüne odaklanıldı ama aşk sözcüğü ile yakın anlamda olan ve anlam bağlantılar1 kurulan sevgi ve sevda gibi sözcükler incelenmedi. Bu sözcükler başka bir araştırmada incelenecektir.

Finansal Destek: Yazarlar bu çalışma için finansal destek almamışlardır.

\section{Kaynakça}

Aksan, Y. ve Aksan, M. (2010). A corpus-based analysis of conceptual love metaphors. Proceedings of the Corpus Linguistics Conference 20-23 July 2009, University of Liverpool.

Aksan, Y. ve Kantar, D. (2008a). No wellness feels better than this sickness: Love metaphors from a crosslinguistic perspective. Metaphor and Symbol, 23, 262-291. doi: 10.1080/10926480802426795

Aksan, Y. ve Kantar, D. (2008b). When love is a journey in English and in Turkey. P. Cap ve J. Nijakowska (Ed.), Current trends in pragmatics içinde (ss. 93-109). Cambridge: Cambridge Scholars Press.

Aksan, Y., Aksan, M., Koltuksuz, A., Sezer, T., Mersinli, Ü., Demirhan, U. U., ... ve Kurtoğlu, Ö. (2012). Construction of the Turkish National Corpus (TNC). Proceedings of the 8th International Conference on Language Resources and Evaluation (LREC 2012). İstanbul, Turkiye. Erişim adresi: http://www.lrec-conf.org/proceedings/lrec2012/papers.html. Erişim tarihi: 1 Aralık 2018.

Anthony, L. (2018). AntConc (Version 3.5.7) [Computer Software]. Tokyo, Japan: Waseda University. Erişim adresi: http://www.laurenceanthony.net/software. Erişim tarihi: 1 Aralık 2018.

Baş, M. (2015). Conceptualization of emotion through body part idioms in Turkish: A cognitive linguistic study (Yayınlanmamış doktora tezi). Hacettepe Üniversitesi, Ankara.

Brezina, V., McEnery, T. ve Wattam, S. (2015). Collocations in context: A new perspective on collocation networks. International Journal of Corpus Linguistics, 20(2), 139-173. doi: 10.1075/ijcl.20.2.01bre 
British Psychological Society (2017). Ethics guidelines for internet-mediated research. INF206/04.2017. Leicester: Author. Erişim adresi: https://www.bps.org.uk/news-and-policy/ethics-guidelinesinternet-mediated-research-2017. Erişim tarihi: 1 Aralık 2018.

Cheung, M. W. L. ve Jak, S. (2016). Analyzing Big Data in psychology: A split/analyze/meta-analyze approach. Frontiers in Psychology, 7, 738. doi: 10.3389/fpsyg.2016.00738

Eichstaedt, J. C., Schwartz, H. A., Kern, M. L., Park, G., Jha, S., Agrawal, M., ... ve Seligman, M. E. P. (2015). Psychological language on Twitter predicts county-level heart disease mortality. Psychological Science, 26(2), 159-169. doi: 10.1177/0956797614557867

Ekman, P. (1992). An argument for basic emotions. Cognition and Emotion, 6(3/4), 169-200. doi: $10.1080 / 02699939208411068$

Felmlee, D. ve Sprecher, S. (2006). Love: Psychological and sociological perspectives. J. E. Stets ve J. H. Turner (Ed.), Handbook of sociology of emotions içinde (ss. 389-409). New York: Springer Press.

Foster, I., Ghani, R., Jarmin, R. S., Kreuter, F. ve Lane, J. (2017). Big Data in social science: A practical guide to methods and tools. New York, NY: CRC Press.

Glynn, D. ve Robinson, J. A. (Ed.) (2014). Corpus methods for semantics: Quantitative studies in polysemy and synonymy. Amsterdam: John Benjamins.

Goldstone, R. L., Kersten, A. ve Carvalho, P. (2017). Categorization and concepts. J. T. Wixted ve S. Thompson-Schill (Ed.), The Stevens' handbook of experimental psychology and cognitive neuroscience içinde (4. bask1, 3. cilt: Language and Thought). New York: Wiley.

Gries, S. T. (2010). Useful statistics for corpus linguistics. A. Sánchez ve M. Almela (Ed.), A mosaic of corpus linguistics: Selected approaches içinde (ss. 269-291). Frankfurt am Main: Peter Lang.

Gries, S. T. (2015). Quantitative designs and statistical techniques. D. Biber ve R. Reppen (Ed.), The Cambridge handbook of English corpus linguistics içinde (ss. 50-71). Cambridge: Cambridge University Press.

Jankowiak, W. R. ve Fischer, E. F. (1992). A cross-cultural perspective on romantic love. Ethonology, 31(2), 149-155. doi: 10.2307/3773618

Kövecses, Z. (1991). A linguist's quest for love. Journal of Social and Personal Relationships, 8(1), 77-97. doi: 10.1177/0265407591081004

Kövecses, Z. (2008). Metaphor and emotion. R. W. Jr. Gibbs (Ed.), The Cambridge handbook of metaphor and thought içinde (ss. 380-396). New York: Cambridge University Press.

Lakoff, G. ve Johnson, M. (1980). Metaphors we live by. Chicago, IL: The University of Chicago Press.

Lee, J. A. (1988). Love-styles. R. J. Sternberg ve M. L. Barnes (Ed.), The psychology of love içinde (ss. 38-67). New Haven: Yale University Press.

Lee, S. W. S. ve Schwarz, N. (2014). Framing love: When it hurts to think we were made for each other. Journal of Experimental Social Psychology, 54, 61-67. doi: 10.1016/j.jesp.2014.04.007

Meyers, S. A. ve Berscheid, E. (1997). The language of love: The difference a preposition makes. Personality and Social Psychology Bulletin, 23(4), 347-362. doi: 10.1177/0146167297234002

Murstein, B. I. (1977). A taxonomy of love. Erişim adresi: https://eric.ed.gov/?id=ED149258. Erişim tarihi: 1 Aralık 2018.

Murstein, B. I. (1988). A taxonomy of love. R. J. Sternberg ve M. L. Barnes (Ed.), The psychology of love içinde (ss. 13-37). New Haven: Yale University Press.

Murty, D. (2018). Twitter: Social communication in the twitter age. Cambridge, UK: Polity Press.

National Institute of Standards and Technology (NIST). (2015). Big data interoperability framework: Volume 1, definitions. Erişim adresi: https://nvlpubs.nist.gov/nistpubs/SpecialPublications/NIST. SP.1500-1.pdf. Erişim tarihi: 06 Mart 2019. doi: 10.6028/NIST.SP.1500-1 
Oakes, M. (1998) Statistics for corpus linguistics. Edinburgh: Edinburgh University Press.

Regan, P. C. (2011). Close relationships. New York, NY: Routledge.

Regan, P. C. (2016). The mating game: A primer on love, sex, and marriage. Thousand Oaks, CA: Sage.

Regan, P. C., Kocan, E. R. ve Whitlock, T. (1998). Aint love grand! A prototype analysis of the concept of romantic love. Journal of Social and Personal Relationships, 15(3), 411-420. doi: $10.1177 / 0265407598153006$

Rempel, J. K. ve Burris, C. T. (2005). Let me count the ways: An integrative theory of love and hate. Personal Relationships, 12(2), 297-313. doi: 10.1111/j.1350-4126.2005.00116.x

Rosch, E. (1978). Principles of categorization. E. Rosch ve B. B. Floyd (Ed.), Cognition and categorization içinde (ss. 27-48). Hillsdale, NJ: Lawrence Erlbaum Assoc.

Rosch, E. (1999). Reclaiming concepts. The Journal of Consciousness Studies, 6(11-12), 61-77.

Rosch, E. ve Mervis, C. B. (1975). Family resemblances: Studies in the internal structure of categories. Cognitive Psychology, 7(4), 573-605. doi: 10.1016/0010-0285(75)90024-9

Schröder, U. A. (2009). Preferential metaphorical conceptualizations in everyday discourse about love in the Brazilian and German speech communities. Metaphor and Symbol, 24(2), 105-120. doi: $10.1080 / 10926480902830862$

Shaver, P. R., Morgan, H. J. ve Wu, S. (1996). Is love a "basic" emotion? Personal Relationships, 3, 83-96. doi: 10.1111/j.1475-6811.1996.tb00105.x

Shaver, P. R., Schwartz, J., Kirson, D. ve O'Connor, C. (1987). Emotion knowledge: Further exploration of a prototype approach. Journal of Personality and Social Psychology, 52, 1061-1086.

Sinclair, J. (1991). Corpus, concordance, collocation. New York, NY: Oxford University Press.

Sinclair, J. (2000). Collins Cobuild English Dictionary for Advanced Learners: Major New Edition (3. Bask1). Collins ELT.

Sinclair, J. (2004). Trust the text: Language, corpus, and discourse. London: Routledge.

Sternberg, R. J. (2006). A dublex theory of love. R. J. Sternberg ve K. Weis (Ed.), The new psychology of love içinde (ss. 184-199). New Haven, CT: Yale University Press.

Stubbs, M. (1995). Collocations and semantic profiles: On the cause of the trouble with quantitative studies. Functions of Language, 2(1), 23-55. doi: 10.1075/fol.2.1.03st

Stubbs, M. (2001). Words and phrases: Corpus studies of lexical semantics. Oxford: Blackwell.

Stubbs, M. (2009). The search for units of meaning: Sinclair on empirical semantics. Applied Linguistics 30(1), 115-137. doi: 10.1093/applin/amn052

Tissari, H. (2001). Metaphors we love by: On the cognitive metaphors of Love from the 15th century to the present. Studia Anglica Posnaniensia, 36, 217-242.

Türk Dil Kurumu Sözlükler. (t.y.). Erişim adresi: http://www.tdk.gov.tr/index.php?option=com_ content\&view=article\&id=645. Erişim tarihi: 01 Aralık 2017.

Williams, M. L., Burnap, P. ve Sloan, L. (2017). Towards an ethical framework for publishing Twitter data in social research: Taking into account users' views, online context and algorithmic estimation. Sociology, 51(6), 1149-1168. doi: 10.1177/0038038517708140 